\title{
BMJ Open Retrospective cross-sectional review of survival rates in critically ill children admitted to a combined paediatric/ neonatal intensive care unit in Johannesburg, South Africa, 2013-2015
}

\author{
Daynia E Ballot, ${ }^{1,2}$ Victor A Davies, ${ }^{1}$ Peter A Cooper, ${ }^{1}$ Tobias Chirwa, ${ }^{3}$ \\ Andrew Argent, ${ }^{4}$ Mervyn Mer $^{2,5}$
}

To cite: Ballot DE, Davies VA, Cooper PA, et al. Retrospective cross-sectional review of survival rates in critically ill children admitted to a combined paediatric/ neonatal intensive care unit in Johannesburg, South Africa, 2013-2015. BMJ Open 2016;6:e010850. doi:10.1136/bmjopen-2015010850

- Prepublication history and additional material is available. To view please visit the journal (http://dx.doi.org/ 10.1136/bmjopen-2015010850).

Received 15 December 2015 Revised 19 February 2016 Accepted 22 March 2016

CrossMark

For numbered affiliations see end of article.

Correspondence to Dr Daynia E Ballot; Daynia.ballot@wits.ac.za

\section{ABSTRACT}

Objective: Report on survival to discharge of children in a combined paediatric/neonatal intensive care unit (PNICU).

Design and setting: Retrospective cross-sectional record review.

Participants: All children (medical and surgical patients) admitted to PNICU between 1 January 2013 and 30 June 2015.

Outcome measures: Primary outcome-survival to discharge. Secondary outcomes-disease profiles and predictors of mortality in different age categories.

Results: There were 1454 admissions, 182 missing records, leaving 1272 admissions for review. Overall mortality rate was $25.7 \%$ (327/1272). Mortality rate was $41.4 \%$ (121/292) (95\% Cl $35.8 \%$ to $47.1 \%)$ for very low birthweight (VLBW) babies, 26.6\% (120/451) $(95 \% \mathrm{Cl} 22.5 \%$ to $30.5 \%)$ for bigger babies and $16.2 \%(86 / 529)(95 \% \mathrm{Cl} 13.1 \%$ to $19.3 \%)$ for paediatric patients. Risk factors for a reduced chance of survival to discharge in paediatric patients included postcardiac arrest (OR $0.21,95 \% \mathrm{Cl} 0.09$ to 0.49 ), inotropic support (OR $0.085,95 \% \mathrm{Cl} 0.04$ to 0.17 ), hypernatraemia (OR $0.16,95 \% \mathrm{Cl} 0.04$ to 0.6 ), bacterial sepsis (OR $0.32,95 \% \mathrm{Cl} 0.16$ to 0.65 ) and lower respiratory tract infection (OR $0.54,95 \% \mathrm{Cl} 0.30$ to 0.97 ). Major birth defects (OR $0.44,95 \% \mathrm{Cl} 0.26$ to $0.74)$, persistent pulmonary hypertension of the new born (OR $0.44,95 \% \mathrm{Cl} 0.21$ to 0.91 ), metabolic acidosis (OR $0.23,95 \% \mathrm{Cl} 0.12$ to 0.74 ), inotropic support (OR $0.23,95 \% \mathrm{Cl} 0.12$ to 0.45 ) and congenital heart defects (OR $0.29,95 \% \mathrm{Cl} 0.13$ to 0.62 ) predicted decreased survival in bigger babies. Birth weight (OR 0.997, 95\% Cl 0.995 to 0.999), birth outside the hospital (OR $0.21,95 \% \mathrm{Cl} 0.05$ to 0.84 ), HIV exposure (OR $0.54,95 \% \mathrm{Cl} 0.30$ to 0.99 ), resuscitation at birth (OR $0.49,95 \% \mathrm{Cl} 0.25$ to 0.94 ), metabolic acidosis (OR $0.25,95 \% \mathrm{Cl} 0.10$ to 0.60 ) and necrotising enterocolitis (OR $0.23,95 \% \mathrm{Cl} 0.12$ to 0.46 ) predicted poor survival in VLBW babies.

Conclusions: Ongoing mortality review is essential to improve provision of paediatric critical care.

\section{Strengths and limitations of this study}

- This is a cross-sectional retrospective review of a large sample of critically ill children cared for in a predominantly neonatal intensive care unit.

- The study adds information about the outcome of critically ill children in sub-Saharan Africa.

- Predictors of mortality are reported for different age categories.

- Severity of illness scoring was not available during the study period, so only unadjusted mortality rates are reported.

- This was a retrospective analysis of a computerised database, so not all records were available for inclusion.

\section{BACKGROUND}

The WHO reports that 5.9 million children under the age of 5 years died in 2015, $75 \%$ of whom were infants (under the age of 1 year), and most infants who died were from the WHO African region. ${ }^{1}$ The outcome of critically ill children may be improved by adequate intensive care. Provision of paediatric and neonatal intensive care in a low-to-middle-income country (LMIC) is challenging. ${ }^{2}$ Difficulties include lack of medical and nursing staff, insufficient medication and equipment and inadequate diagnostic facilities. ${ }^{2}{ }^{3}$ Identifying the optimal use of paediatric intensive care unit (PICU) beds in a resource-limited situation is difficult. The ICU admission criteria attempt to ensure that the limited facilities benefit those who will gain most; children without a reasonable chance of functional recovery are not routinely admitted to PICU. ${ }^{2} 4$ Argent et $a l^{4}$ discussed an approach to optimising the use of limited PICU facilities at the Red Cross War Memorial Children's Hospital 
(RCWMCH) in Cape Town, South Africa, stating that hospitals need to develop 'explicit policies for utilisation of PICU resources' using 'a reasonable process for fair and equitable utilisation of scarce resources... that may extend beyond the priorities of individual patients'.

Mortality and infection rates in PICU in developing countries are influenced by the income level of the country. ${ }^{5}$ The average PICU mortality rate in Latin American countries was $13.39 \%$ compared with $5.4 \%$ in European countries. ${ }^{6}$ The mean PICU mortality rate in Turkey was reported to be $14.6 \%{ }^{3}$ PICU mortality at the RCWMCH in Cape Town, however, has declined from $10.6 \%$ in 2006 to $9 \%$ in $2010 .{ }^{4} 7$ The mortality rate of children admitted to general ICU facilities in other African countries is far higher than the RCWMCH experience, ranging from $36 \%$ to $40 \% .^{8-10}$

Children admitted to a centralised dedicated paediatric ICU have better survival rates than those treated in general or shared ICU facilities, even in developing countries. ${ }^{11}{ }^{12}$ Dedicated PICU facilities are uncommon in South Africa. Critical care beds in South Africa are concentrated in the more affluent provinces (Gauteng, KwaZulu-Natal and the Western Cape) and in the private sector. ${ }^{13}{ }^{14}$ Only $19.6 \%$ of the total ICU beds were for paediatric and neonatal intensive care, and mixed surgical and medical units admit children in most hospitals. ${ }^{13}$ Lack of dedicated PICU facilities is common in many other African countries. In Uganda, for example, there is one general ICU bed per million people. ${ }^{10}$

Charlotte Maxeke Johannesburg Academic Hospital (CMJAH) is a quaternary referral hospital with a single combined paediatric/neonatal ICU (PNICU) with 14 ventilator beds. This unit serves neonates, general paediatrics, paediatric subspecialities and paediatric surgery; renal dialysis and high-frequency ventilation are available. The age of admission ranges from birth to 14 years. It is often not possible to admit patients because of a lack of available beds. The unit has no dedicated paediatric intensivist but is run by other subspecialists, mainly neonatologists. Nasal continuous positive airway pressure (NCPAP) is the first line of ventilatory support for neonates with respiratory failure. ${ }^{15}$ Patients who require 'high-care' observation or treatment are not routinely admitted; the PNICU essentially functions as a ventilator unit. Additional information regarding the CMJAH PNICU is provided in the online supplementary material file, available online. There is a lack of information on admissions to the CMJAH PNICU. This study therefore aimed to review the survival to discharge of patients admitted to the unit. Secondary objectives included comparing the survival rate between paediatric and neonatal patients, determining the disease profile of patients and establishing predictors or factors associated with poor survival.

\section{PATIENTS AND METHODS}

This was a retrospective cross-sectional record review of all patients admitted to the CMJAH PNICU between 1
January 2013 and 30 June 2015. The PNICU admitted neonates and older children who suffered from medical or surgical conditions. Patients were admitted and cared for at the discretion of the attending physician, using age-related norms and treatment protocols. Owing to limited availability of PNICU beds, patients with an anticipated poor outcome, including those with advanced HIV-related disease, were not routinely ventilated. Similarly, neonates below $900 \mathrm{~g}$ birth weight were not usually offered mechanical ventilation. Exposure to HIV alone was not a reason for exclusion from PNICU.

Patient charts were reviewed on discharge from PNICU, and demographic, clinical and outcome data were captured. Variables were recorded as positive if there had been any occurrence during their time in the PNICU. Detailed definitions of the variables used in the study are provided in the online supplementary file, available online.

Patient data were entered into computerised databases for clinical audit and quality improvement. These databases are managed by Research Electronic Data Capture (REDCap) hosted by the University of the Witwatersrand. ${ }^{16}$ The data were deidentified and entered into IBM SPSS (V.22) for the purposes of analysis. Patients with no retrievable information were excluded from the study.

\section{Definitions of patient categories}

The group of patients was divided into paediatric patients ( $>28$ days of age) and neonates. Neonates were classified as those $<28$ days of age who had never been discharged home, and who had been admitted directly to PNICU from other hospitals or the neonatal nursery at CMJAH. Neonates who had been discharged home and then readmitted to PNICU were classified as paediatric patients. Neonates were further divided into very low birthweight (VLBW) infants $(<1500 \mathrm{~g}$ birth weight) and bigger babies $(\geq 1500 \mathrm{~g}$ birth weight). Children older than 14 years were usually admitted to the adult ICU. All neonates admitted to PNICU in this study were intubated and ventilated; some paediatric patients were not intubated but admitted for high-care treatment.

Surgical patients were defined as all children who presented with a surgical condition. Postoperative admissions defined those surgical patients who were electively admitted to PNICU post surgery.

\section{Statistical analysis}

Continuous variables such as age at admission were described using mean and SD or median with IQR, depending on whether the data were normally distributed. Categorical variables were described as frequencies and percentages. Survival to discharge from ICU was considered the primary outcome variable for comparison.

Univariate analysis comparing different characteristics between survivors and non-survivors used an independent t-test for normally distributed data and the 
Mann-Whitney U test for skewed data. A $\chi^{2}$ test was used to compare differences in survival for categorical variables. A $p$ value of $<0.05$ was considered to be statistically significant. Variables with a $\mathrm{p}$ value $<0.05$ in the univariate analysis were entered into a multiple stepwise logistic regression model to establish determinants of survival to PNICU discharge. Neonates and older paediatric patients have different disease profiles and different risk factors for mortality. Data were therefore analysed separately for VLBW, bigger babies and paediatric patients.

\section{RESULTS}

A total of 1454 patients were admitted to the PNICU during the study period. Records could not be retrieved for 182 patients, so the study included 1272 patients. There were 292 VLBW babies (22.9\%), 451 bigger babies $(35.4 \%)$ and 529 paediatric $(41.5 \%)$ admissions. The overall proportion dying was $25.7 \%$ (327/1272). There was a statistically significant difference in the proportion of deaths between patients of different ages, with the death rate being $41.4 \%(121 / 292) \quad(95 \%$ CI $35.8 \%$ to $47.1 \%)$ in VLBW babies, $26.6 \%(120 / 451)$ (95\% CI $22.5 \%$ to $30.5 \%$ ) in bigger babies and $16.2 \%$
$(86 / 529)(95 \%$ CI $13.1 \%$ to $19.3 \%)$ in paediatric patients $(\mathrm{p}<0.0001)$.

\section{Paediatric ICU admissions}

Details of the 529 paediatric admissions are shown in table 1 . The median age at admission was 8.7 months $(I Q R=46.5)$. There was no statistically significant difference in the median age of admissions between survivors and non-survivors (10.5 months $(\mathrm{IQR}=50.7) \quad$ vs 7.3 months $(\mathrm{IQR}=35.7) ; \mathrm{p}=0.412)$. Similarly, the median duration of ICU stay was not significantly different for survivors and non-survivors ( 23 days in both groups; $\mathrm{p}=0.540)$. The majority of patients $(471 / 529 ; 89 \%)$ were intubated and ventilated. More than half (305/529; $57.7 \%$ ) of the paediatric patients were surgical admissions. The most common problem in medical paediatric patients was lower respiratory tract illness (191/529; $36.1 \%)$.

Binary logistic regression analysis with survival to discharge from PNICU as the outcome variable showed that poor outcome was associated with postcardiac arrest (OR $0.21,95 \%$ CI 0.09 to 0.49 ), inotropic support (OR $0.085,95 \%$ CI 0.04 to 0.17 ), hypernatraemia (OR 0.16,

Table 1 Factors associated with survival in the 529 paediatric patients admitted to CMJAH PNICU between 1 January 2013 and 30 June 2015

\begin{tabular}{|c|c|c|c|c|}
\hline Variable & $\begin{array}{l}\text { Children with the } \\
\text { condition (\%) }\end{array}$ & $\begin{array}{l}\text { Percentage of children with } \\
\text { the condition that died } \\
(95 \% \mathrm{Cl})\end{array}$ & $\begin{array}{l}\text { Percentage of children without } \\
\text { the condition that died }(95 \% \mathrm{Cl})\end{array}$ & $\begin{array}{l}p \\
\text { Value }\end{array}$ \\
\hline Male & $292(55.2)$ & 16.1 (11.9 to 20.3$)$ & 17.4 (12.3 to 22.5$)$ & 0.477 \\
\hline HIV exposed* & $106(20)$ & 30.2 (21.5 to 38.9$)$ & $12.2(9.1$ to 16.1$)$ & $<0.001$ \\
\hline HIV PCR positive* & $30(5.7)$ & 30 (13.6 to 46.4$)$ & $15.4(12.2$ to 18.6$)$ & 0.036 \\
\hline Recurrent admission & $52(9.8)$ & 11.5 (2.8 to 20.1$)$ & 16.8 (13.4 to 20.2$)$ & 0.604 \\
\hline Postcardiac arrest* & $34(6.4)$ & 47 (30.2 to 63.8) & $13.4(10.4$ to 16.4$)$ & $<0.001$ \\
\hline Intubated and ventilated & 471 (89) & 17.2 (13.8 to 20.6$)$ & $8.6(1.3$ to 15.8$)$ & 0.095 \\
\hline Surgical patients* & $305(57.7)$ & $9.8(6.3$ to 13.3$)$ & 25.0 (19.3 to 30.7$)$ & $<0.001$ \\
\hline Postoperative $^{\star}$ & $239(45.2)$ & 7.5 (4.2 to 10.8$)$ & 23.6 (18.7 to 28.6$)$ & $<0.001$ \\
\hline Trauma & 75 (14.2) & 18.6 (9.8 to 27.4$)$ & 15.8 (12.4 to 19.2$)$ & 0.542 \\
\hline Inotropic support* & $53(10.0)$ & 60.4 (47.2 to 73.6$)$ & $11.2(8.3$ to 14.1$)$ & $<0.001$ \\
\hline Upper respiratory tract* & $61(11.5)$ & 6.5 (0.3 to 12.7$)$ & 17.5 (14.6 to 20.9 ) & 0.029 \\
\hline Lower respiratory tract ${ }^{\star}$ & $191(36.1)$ & 25.6 (19.4 to 31.8$)$ & 10.9 (7.6 to 14.2$)$ & $<0.001$ \\
\hline Cardiovascular* & 97 (18.3) & 28.9 (19.9 to 37.9$)$ & $13.4(10.2$ to 16.6$)$ & $<0.001$ \\
\hline Neurological & $125(23.6)$ & 22.5 (15.2 to 29.9$)$ & 16.7 (12.8 to 20.6$)$ & 0.086 \\
\hline Gastrointestinal* $^{*}$ & 65 (12.3) & 26.1 (15.4 to 36.8$)$ & $14.9(11.7$ to 18.1$)$ & 0.021 \\
\hline Renal $^{*}$ & $18(3.4)$ & $29.4(6.3$ to 52.5$)$ & $15.6(12.5$ to 18.8$)$ & 0.024 \\
\hline $\begin{array}{l}\text { Haematology/oncology } \\
\text { (incl. anaemia) }\end{array}$ & $108(20.4)$ & 13.8 (7.3 to 20.3$)$ & 16.8 (13.2 to 20.4$)$ & 0.559 \\
\hline Hypernatraemia* & $15(2.8)$ & 33.3 (9.5 to 15.2$)$ & $14.8(11.7$ to 17.9$)$ & $<0.001$ \\
\hline Hyperglycaemia* & $6(1.1)$ & 50 (9.9 to 90.0$)$ & $15.8(12.7$ to 18.9$)$ & 0.024 \\
\hline Hypoglycaemia* & $11(2.1)$ & 45.4 (15.9 to 74.8$)$ & $15.6(12.7$ to 18.7$)$ & 0.008 \\
\hline Metabolic acidosis* & $26(4.9)$ & 46.2 (27.0 to 65.4$)$ & 14.7 (11.6 to 17.8$)$ & $<0.001$ \\
\hline Poisoning & $17(3.2)$ & 23.5 (3.3 to 43.7 ) & 15.8 (12.6 to 19.0$)$ & 0.494 \\
\hline Drowning & 7 (1.3) & 14.2 (11.7 to 40.1$)$ & 16.4 (13.2 to 19.6$)$ & 0.824 \\
\hline Bacterial sepsis* & $64(12.1)$ & 32.8 (21.3 to 44.3$)$ & 13.7 (10.5 to 16.9$)$ & $<0.001$ \\
\hline Viral infection & $34(6.4)$ & 17.6 (4.8 to 30.4$)$ & 16.2 (12.9 to 19.5$)$ & 0.974 \\
\hline Fungal infection & $16(3.0)$ & 31 (8.3 to 51.7) & $15.6(12.4$ to 18.8$)$ & 0.229 \\
\hline
\end{tabular}

*Statistically significant predictors of survival on univariate analysis.

CMJAH, Charlotte Maxeke Johannesburg Academic Hospital; PNICU, paediatric/neonatal intensive care unit. 
95\% CI 0.04 to 0.6 ), bacterial sepsis (OR $0.32,95 \%$ CI 0.16 to 0.65 ) and lower respiratory tract infection (OR $0.54,95 \%$ CI 0.30 to 0.97 ). Postoperative patients were very unlikely to die during the PNICU admission (OR $2.96,95 \%$ CI 1.49 to 5.92 ).

\section{Bigger babies}

Characteristics of the 451 bigger babies admitted to PNICU and factors associated with their survival to ICU discharge are shown in table 2. The median duration of ventilation for bigger babies was 3 days $(\mathrm{IQR}=75)$. The babies who died had a significantly shorter duration of ventilation compared with survivors ( 2 days $(\mathrm{IQR}=6)$ vs 4 days $(\mathrm{IQR}=6) ; \mathrm{p}<0.001)$. The mean gestational age of bigger babies admitted to PNICU was $36.97 \pm 3.6$ weeks and mean birth weight was $2603 \pm 736 \mathrm{~g}$. There were no statistically significant differences between survivors and non-survivors in gestational age $(36.89 \pm 3.6$ vs 37.23 \pm 3.5 weeks; $\mathrm{p}=0.404)$ or birth weight $(2617 \pm 763$ vs 2576 $\pm 663 \mathrm{~g} ; \mathrm{p}=0.615)$. Binary logistic regression showed that birth weight did not influence survival in this subcategory $(\mathrm{p}=0.614)$. Just over one-third of bigger babies $(34.3 \%)$ were surgical patients.
Binary logistic regression analysis for factors associated with survival in bigger babies showed major birth defects (OR $0.44,95 \%$ CI 0.26 to 0.74 ), persistent pulmonary hypertension of the neonate (PPHN) (OR 0.44, 95\% CI 0.21 to 0.91 ), metabolic acidosis (OR $0.23,95 \%$ CI 0.12 to 0.74 ), inotropic support (OR $0.23,95 \%$ CI 0.12 to 0.45 ) and congenital heart disease (CHD) (OR 0.29, $95 \%$ CI 0.13 to 0.62 ), all predictive of poor survival.

\section{VLBW babies}

Characteristics of the 292 VLBW babies admitted to the PNICU are shown in table 3 . The mean birth weight was $1133.2 \pm 182 \mathrm{~g}$ and mean gestational age 28.95 \pm 8.17 weeks. There were no statistically significant differences between survivors and non-survivors in mean birth weight $(1149 \pm 182$ vs $1109 \pm 180 \mathrm{~g} ; \mathrm{p}=0.063)$ or gestational age $\quad(29.01 \pm 2.1$ vs $28.86 \pm 2.1$ weeks; $\mathrm{p}=0.540)$. The median duration of ventilation was 5 days $(\mathrm{IQR}=8)$. The duration of ventilation was significantly shorter in VLBW babies who died ( 4 days $(\mathrm{IQR}=10)$ vs 6 days $(\mathrm{IQR}=7)$; $\mathrm{p}<0.001)$.

Binary logistic regression showed that the following factors were associated with reduced survival in VLBW

Table 2 Characteristics and predictors of survival in 451 bigger babies admitted to CMJAH PNICU between 1 January 2013 and 30 June 2015

\begin{tabular}{|c|c|c|c|c|}
\hline Variable & $\begin{array}{l}\text { Children with } \\
\text { the condition } \\
(\%)\end{array}$ & $\begin{array}{l}\text { Percentage of babies with the } \\
\text { condition that died }(95 \% \mathrm{Cl})\end{array}$ & $\begin{array}{l}\text { Percentage of babies without } \\
\text { the condition that died }(95 \% \mathrm{Cl})\end{array}$ & $\begin{array}{l}p \\
\text { Value }\end{array}$ \\
\hline \multicolumn{5}{|l|}{ Place of birth } \\
\hline Another unit & $220(48.7)$ & 34.1 (27.8 to 40.4$)$ & & 0.577 \\
\hline $\begin{array}{l}\text { Born outside health } \\
\text { facility }\end{array}$ & $14(3.1)$ & 28.6 (4.9 to 52.3 ) & & \\
\hline CMJAH & $186(41.2)$ & 30.1 (23.5 to 36.7 ) & & \\
\hline Antenatal care & $302(67)$ & 27.2 (22.2 to 32.2$)$ & 26.8 (18.0 to 35.6 ) & 0.827 \\
\hline Maternal HIV & 127 (28.2) & $32.3(24.2-40.4)$ & $24.9(20.0-29.9)$ & 0.231 \\
\hline Caesarean section & $169(37.4)$ & 23.6 (17.0 to 30.2$)$ & 32.9 (25.9 to 40.0$)$ & 0.31 \\
\hline Male & $274(60.8)$ & 27.7 (22.4 to 33.0$)$ & 25.3 (18.8 to 31.8$)$ & 0.491 \\
\hline Resuscitated at birth & 98 (21.7) & 28.6 (19.7 to 37.6$)$ & $26.1(21.5$ to 30.7$)$ & 0.619 \\
\hline Early-onset sepsis & $20(4.4)$ & 20 (2.5 to 37.5$)$ & 27.1 (22.8 to 31.4$)$ & 0.664 \\
\hline Meconium aspiration & 75 (16.6) & 25.3 (15.5 to 35.1$)$ & 26.9 (22.4 to 31.4$)$ & 0.784 \\
\hline $\begin{array}{l}\text { Hyaline membrane } \\
\text { disease* }^{\star}\end{array}$ & 89 (19.7) & 16.9 (9.1 to 24.7$)$ & 29.0 (24.3 to 33.7$)$ & 0.02 \\
\hline $\mathrm{PPHN}^{*}$ & $45(10.0)$ & 46.7 (32.1 to 61.3$)$ & 24.4 (20.2 to 28.6$)$ & 0.002 \\
\hline Surfactant therapy & 108 (23.9) & 21.3 (13.4 to 29.0$)$ & 28.7 (13.4 to 29.0$)$ & 0.518 \\
\hline $\begin{array}{l}\text { Hypotension requiring } \\
\text { inotropes* }\end{array}$ & 55 (12.2) & 54.5 (41.3 to 67.7$)$ & 22.7 (18.6 to 26.8$)$ & $<0.001$ \\
\hline $\mathrm{CHD}^{*}$ & 37 (8.2) & 54.1 (38.0 to 70.2$)$ & 25.3 (21.1 to 29.5$)$ & $<0.001$ \\
\hline NEC & $43(9.5)$ & 37.2 (22.8 to 51.7$)$ & 25.3 (21.1 to 29.5$)$ & 0.35 \\
\hline $\begin{array}{l}\text { Surgery (excluding } \\
\text { NEC) }\end{array}$ & $129(28.6)$ & 23.3 (16.0 to 30.6 ) & 28.0 (23.1 to 32.9$)$ & 0.395 \\
\hline Hyperglycaemia* & $46(10.2)$ & 41.3 (27.1 to 55.5$)$ & 24.9 (20.7 to 29.1$)$ & 0.017 \\
\hline Metabolic acidosis* & 48 (10.6) & 56.3 (42.3 to 70.3$)$ & 23.1 (19.0 to 27.2 ) & $<0.001$ \\
\hline Late-onset sepsis & $119(26.4)$ & 29.4 (21.2 to 37.6$)$ & 25.6 (20.9 to 30.3$)$ & 0.420 \\
\hline Major birth defect ${ }^{*}$ & $146(32.4)$ & 36.3 (28.5 to 44.1$)$ & 22.0 (17.4 to 26.7$)$ & 0.002 \\
\hline
\end{tabular}


Table 3 Characteristics and predictors of survival for 292 VLBW babies admitted to the CMJAH PNICU between 1 January 2013 and 30 June 2015

\begin{tabular}{|c|c|c|c|c|}
\hline Variable & $\begin{array}{l}\text { Babies with the } \\
\text { condition (\%) }\end{array}$ & $\begin{array}{l}\text { Percentage of babies with the } \\
\text { condition that died }(95 \% \mathrm{Cl})\end{array}$ & $\begin{array}{l}\text { Percentage of babies without } \\
\text { the condition that died }(95 \% \mathrm{Cl})\end{array}$ & $\begin{array}{l}\mathbf{p} \\
\text { Value }\end{array}$ \\
\hline \multicolumn{5}{|l|}{ Place of birth ${ }^{\star}$} \\
\hline $\begin{array}{l}\text { Born outside health } \\
\text { facility }\end{array}$ & $19(6.5)$ & 68.4 (47.5 to 89.3 ) & & 0.008 \\
\hline Born at another unit & 97 (33.2) & 32.0 (22.7 to 41.3$)$ & & \\
\hline Born at CMJAH & 176 (60.3) & 43.8 (36.5 to 51.1$)$ & & \\
\hline Antenatal care & $171(58.6)$ & 39.8 (32.5 to 47.1$)$ & 43.8 (35.0 to 52.6 ) & 0.49 \\
\hline Antenatal steroids & $86(29.5)$ & 43.0 (32.5 to 53.5$)$ & 40.8 (34.1 to 47.5$)$ & 0.722 \\
\hline Maternal HIV & 98 (33.6) & 49.0 (39.1 to 58.9$)$ & 37.6 (30.8 to 44.4$)$ & 0.063 \\
\hline Caesarean section & $124(42.5)$ & 39.5 (30.9 to 48.1$)$ & 44.2 (35.7 to 52.7$)$ & 0.817 \\
\hline Male & 164 (56.2) & 42.7 (35.1 to 50.3$)$ & 40.2 (31.7 to 48.7$)$ & 0.638 \\
\hline $\begin{array}{l}\text { Resuscitated at } \\
\text { birth }\end{array}$ & $112(38.4)$ & 50.9 (41.6 to 60.2$)$ & 35.6 (28.6 to 42.6 ) & 0.099 \\
\hline Early-onset sepsis & $10(3.4)$ & 60 (29.6 to 90.4$)$ & 39.8 (33.9 to 45.7$)$ & 0.358 \\
\hline IVH $34^{*}$ & $32(10.9)$ & 53.1 (35.8 to 70.4$)$ & 33.3 (26.6 to 40.0$)$ & $<0.001$ \\
\hline $\begin{array}{l}\text { Hyaline membrane } \\
\text { disease }\end{array}$ & $268(91.8)$ & 41.4 (35.5 to 47.3$)$ & $41.6(21.9$ to 61.3$)$ & 0.981 \\
\hline Surfactant & $228(78.1)$ & 39.9 (33.5 to 46.3$)$ & 46.9 (34.7 to 59.1$)$ & 0.318 \\
\hline $\begin{array}{l}\text { Patent ductus } \\
\text { arteriosus* }\end{array}$ & $83(28.4)$ & 26.5 (17.0 to 36.0 ) & 47.3 (40.5 to 54.1$)$ & $<0.001$ \\
\hline NEC ${ }^{*}$ & $72(24.7)$ & 62.5 (51.3 to 73.7$)$ & 34.5 (28.2 to 40.8$)$ & $<0.001$ \\
\hline NEC surgery* & 39 (13.4) & 56.4 (40.8 to 72.0$)$ & 39.1 (33.1 to 45.1$)$ & 0.041 \\
\hline Other surgery & 36 (12.3) & 50 (33.7 to 66.3) & 40.2 (34.2 to 46.2$)$ & 0.265 \\
\hline Blood transfusion & $88(30.1)$ & 38.7 (32.0 to 45.4$)$ & 47.7 (37.3 to 58.1$)$ & 0.152 \\
\hline Hyperglycaemia & 68 (22.3) & 51.5 (39.6 to 63.4$)$ & 38.4 (32.0 to 44.8$)$ & 0.055 \\
\hline Hypoglycaemia & 38 (13.0) & 42.1 (26.4 to 57.8$)$ & 41.3 (35.2 to 47.4$)$ & 0.929 \\
\hline Hypernatraemia & $22(7.5)$ & 40.9 (20.4 to 61.4$)$ & 41.5 (35.6 to 47.4$)$ & 0.958 \\
\hline Metabolic acidosis* & 39 (13.4) & 19.2 (54.7 to 83.7) & 37.2 (31.2 to 43.2$)$ & $<0.001$ \\
\hline Late-onset sepsis & $142(48.6)$ & 39.3 (31.5 to 47.1$)$ & 43.7 (35.5 to 51.9$)$ & 0.453 \\
\hline Major birth defect & $19(6.5)$ & 42.1 (19.9 to 64.3$)$ & 41.4 (36.4 to 46.4$)$ & 0.951 \\
\hline
\end{tabular}

*Statistically significant predictors of survival on univariate analysis.

CMJAH, Charlotte Maxeke Johannesburg Academic Hospital; IVH, intraventricular haemorrhage; NEC, necrotising enterocolitis; PNICU, paediatric/neonatal intensive care unit.

babies: birth weight (OR 0.997, 95\% CI 0.995 to 0.999$)$, born before arrival (OR $0.21,95 \%$ CI 0.05 to 0.84 ), maternal HIV exposure (OR $0.54,95 \%$ CI 0.30 to 0.99 ), resuscitation at birth (OR 0.49 , 95\% CI 0.25 to 0.94 ), metabolic acidosis (OR $0.25,95 \%$ CI 0.10 to 0.60 ) and necrotising enterocolitis (NEC) (OR $0.23,95 \%$ CI 0.12 to 0.46$)$.

\section{DISCUSSION}

This review of admissions to a combined PNICU shows an overall mortality rate of $25.7 \%$. The paediatric mortality rate was $16.2 \%$. This is higher than the mortality rate at the dedicated paediatric ICU at $\mathrm{RCWMCH}^{4}$ but lower than that reported for children admitted to general ICUs in other African countries. ${ }^{8-10}$

Possible reasons for the high mortality rate in this study may lie outside the PNICU, such as late referral and inadequate resuscitation, or within, such as insufficient beds and inadequate staffing. The lack of a paediatric intensivist may partly contribute to the mortality rate; dedicated paediatric intensivists have been shown to reduce the mortality rate of children in ICU and improve bed utilisation. ${ }^{17}$ This PNICU was run mainly as an invasive ventilator unit, with limited high-dependency care admissions; $89 \%$ of the paediatric patients and all neonates admitted to PNICU were intubated and ventilated. Therefore, this may represent a sicker cohort of children compared with other PICUs. Mortality prediction risk scores such as the Paediatric Index of Mortality (PIM) allow objective comparisons between different units. ${ }^{18}$ Although PIM data were not collected during the study period, the predictors of poor outcome in the current study were similar to the PIM, including postcardiac arrest, inotropic support and metabolic acidosis.

The mortality was higher in neonates than paediatric patients. Mortality of ventilated neonates was similar to that reported from units in India. ${ }^{19}$ The very high mortality of the VLBW group in the PNICU is not surprising as these patients had failed initial NCPAP and were therefore very sick babies. The mortality rate of ventilated VLBW infants was similar to that reported in a study in China. ${ }^{20}$ Birth weight, the strongest predictor of outcome in VLBW infants in our setting, ${ }^{21}$ remained a 
significant factor associated with survival in the ventilated VLBW babies.

HIV infection and HIV exposure were significant predictors of outcome in the univariate analysis, but not in the logistic regression. There is, however, selection bias, as only those HIV-exposed infants who were expected to recover were admitted to the PNICU.

Other potential sources of bias were considered. The age of paediatric patients was skewed towards younger children who would be expected to have a higher mortality than their older counterparts. There was a slight preponderance of infants $(<1$ year of age) in the paediatric age group $(274 / 529(51.8 \%))$. However, there was no significant difference in the number of deaths between infants and older children (53/274 (19.3\%) vs $33 / 245(13.5 \%) \mathrm{p}=0.077)$. Similarly, neonates weighing $>2500 \mathrm{~g}$ are expected to have a different disease profile and mortality rate from those weighing $<2500 \mathrm{~g}$. Babies $>2500 \mathrm{~g}$ could therefore have been another source of bias in the category of bigger babies; however, binary logistic regression showed that birth weight did not influence survival in this category $(\mathrm{p}=0.614)$.

There were some apparent anomalies in our data. The low incidence of viral infections and hyperglycaemia may reflect lack of active surveillance for these conditions. The low number of fungal isolates may be explained by the fact that fungal organisms are difficult to isolate on paediatric low-volume blood cultures.

This study raises the issue of children's rights to healthcare. A report from 2007 showed that only 19.6\% of the ICU beds in South Africa are dedicated to the care of children. ${ }^{13}$ Our study raises the issue of balancing the rights of older children against those of neonates in a combined PNICU. Only the very sickest neonates (those who failed NCPAP) were admitted to the PNICU, which may be a form of discrimination. There are no easy ways to identify which patients to admit to PNICU, especially in a resource-limited setting. ${ }^{2}{ }^{4}$ Children must not come to ICU to die, yet many who are critically ill, with an increased risk of death, may have a better chance of recovery if treated in ICU. We found that postoperative patients had good outcomes, which may reflect the optimal use of ventilator beds in this unit, or may indicate that many of these patients did not require ICU. Increasing the number of 'high-care' admissions would decrease the PNICU mortality rate, but this would often be at the expense of a sicker child requiring ventilation.

This study had several limitations. The raw proportion of deaths in the CMJAH PNICU is higher than other units but may reflect a different level of severity of illness. As may be the case with retrospective analyses, not all information was available for inclusion in the study. The use of a standardised illness code such as the Australian and New Zealand practice in intensive care (ANZPIC) system may have been preferable. $^{22}$

\section{CONCLUSIONS AND RECOMMENDATIONS}

The unadjusted mortality rate of children admitted to this combined PNICU is higher than that reported in a dedicated PICU in the same country. ${ }^{4}$ Incorporation of a paediatric intensivist, even in poorer countries, improves the outcome for children, both in terms of mortality and length of stay. ${ }^{11}{ }^{17}$ Ongoing training in the stabilisation and management of critically ill children is essential for all paediatric registrars, general paediatricians and other subspecialists. Future clinical audits should include a severity of illness score such as the $\mathrm{PIM},{ }^{22}$ hospital paediatric mortality rate and the number of children denied admission to PNICU, together with outcome data.

\section{Author affiliations}

${ }^{1}$ Department of Paediatrics and Child Health, Faculty of Health Sciences, University of the Witwatersrand, Johannesburg, South Africa

${ }^{2}$ Wits- UQ Critical Care Infection Collaboration, Johannesburg, South Africa ${ }^{3}$ Division of Epidemiology and Biostatistics, Faculty of Health Sciences, School of Public Health, University of the Witwatersrand, Johannesburg, South Africa

${ }^{4}$ Faculty of Health Sciences, School of Child and Adolescent Health, University of Cape Town, Cape Town, South Africa

${ }^{5}$ Department of Internal Medicine, Division of Critical Care and Pulmonology, Faculty of Health Sciences, University of the Witwatersrand, Johannesburg, South Africa

Acknowledgements The authors gratefully acknowledge the help of $\mathrm{Dr}$ Debbie White, Dr Edgar Kalimba, Dr Priya Wallabh, Dr Lea Chirwa, Dr Tanusha Ramdin, Dr David Raketsoane and Dr Faustine Agaba with data collection, and Mr Lebogang Rapola, Miss Patricia Hanrahan and Mr Milton Reinecke with data management

Contributors DEB conceptualised the study, collected and analysed the data and wrote the manuscript. VAD assisted with the concept, data collection and reviewed the write-up of the manuscript. PAC assisted with the study concept and review of the write-up of the manuscript. TC assisted with data analysis and review of the write-up of the manuscript. AA and MM provided advice and input to the final write-up of the manuscript.

Funding This research received no specific grant from any funding agency in the public, commercial or not-for-profit sectors.

Competing interests None declared.

Ethics approval Human Research Ethics Committee of the University of the Witwatersrand.

Provenance and peer review Not commissioned; externally peer reviewed.

Data sharing statement No additional data are available.

Open Access This is an Open Access article distributed in accordance with the Creative Commons Attribution Non Commercial (CC BY-NC 4.0) license, which permits others to distribute, remix, adapt, build upon this work noncommercially, and license their derivative works on different terms, provided the original work is properly cited and the use is non-commercial. See: http:// creativecommons.org/licenses/by-nc/4.0/

\section{REFERENCES}

1. WHO. Global Health Observatory Data. 2015 (cited 27 January 2016). http://www.who.int/gho/child_health/mortality/neonatal_infant_ text/en/

2. Basnet S, Adhikari N, Koirala J. Challenges in setting up pediatric and neonatal intensive care units in a resource-limited country. Pediatrics 2011;128:e986-92.

3. Koroglu TF, Atasever S, Duman M. A survey of pediatric intensive care services in Turkey. Turk J Pediatr 2008;50:12-17. 
4. Argent AC, Ahrens J, Morrow BM, et al. Pediatric intensive care in South Africa: an account of making optimum use of limited resources at the Red Cross War Memorial Children's Hospital*. Pediatr Crit Care Med 2014:15:7-14.

5. Rosenthal VD, Jarvis WR, Jamulitrat S, et al., International Nosocomial Infection Control Members. Socioeconomic impact on device-associated infections in pediatric intensive care units of 16 limited-resource countries: international Nosocomial Infection Control Consortium findings. Pediatr Crit Care Med 2012;13:99-406.

6. Campos-Mino S, Sasbón JS, von Dessauer B. [Pediatric intensive care in Latin America]. Med Intensiva 2012;36:3-10.

7. Ghani AS, Morrow BM, Hardie DR, et al. An investigation into the prevalence and outcome of patients admitted to a pediatric intensive care unit with viral respiratory tract infections in Cape Town, South Africa. Pediatr Crit Care Med 2012;13:e275-81.

8. Embu HY, Yiltok SJ, Isamade ES, et al. Paediatric admissions and outcome in a general intensive care unit. Afr J Paediatr Surg 2011;8:57-61.

9. El-Nawawy A. Evaluation of the outcome of patients admitted to the pediatric intensive care unit in Alexandria using the pediatric risk of mortality (PRISM) score. J Trop Pediatr 2003;49:109-14.

10. Kwizera A, Dunser M, Nakibuuka J. National intensive care unit bed capacity and ICU patient characteristics in a low income country. BMC Res Notes 2012;5:475.

11. Pearson G, Shann F, Barry $P$, et al. Should paediatric intensive care be centralised? Trent versus Victoria. Lancet 1997;349:1213-17.

12. Goh AY, Lum LC, Abdel-Latif ME. Impact of 24 hour critical care physician staffing on case-mix adjusted mortality in paediatric intensive care. Lancet 2001;357:445-6.

13. Bhagwanjee $\mathrm{S}$, Scribante J. National audit of critical care resources in South Africa一 unit and bed distribution. S Afr Med J 2007;97(Pt 3):1311-14
14. Naidoo K, Singh J, Lalloo U. A critical analysis of ICU/HC beds in South Africa: 2008-2009. S Afr Med J 2013;103:751-3.

15. Jardine CBallot DE. The use of nasal CPAP at Charlotte Maxeke Johannesburg Academic Hospital. S Afr J Child Health 2015;9:4.

16. Harris PA, Taylor R, Thielke R, et al. Research electronic data capture (REDCap)-a metadata-driven methodology and workflow process for providing translational research informatics support. J Biomed Inform 2009;42:377-81.

17. Pollack MM, Katz RW, Ruttimann UE, et al. Improving the outcome and efficiency of intensive care: the impact of an intensivist. Crit Care Med 1988;16:11-17.

18. Straney L, Clements A, Parslow RC, et al., ANZICS Paediatric Study Group and the Paediatric Intensive Care Audit Network. Paediatric index of mortality 3: an updated model for predicting mortality in pediatric intensive care ${ }^{\star}$. Pediatr Crit Care Med 2013;14:673-81.

19. Iqbal Q, Younus MM, Ahmed A, et al. Neonatal mechanical ventilation: indications and outcome. Indian J Crit Care Med 2015;19:523-7.

20. Ma L, Liu CQ, Meng LZ, et al. [Prospective study on in-hospital mortality and its risk factors in very low birth weight infants requiring mechanical ventilation]. Zhongguo Dang Dai Er Ke Za Zhi 2012;14:737-41.

21. Ballot DE, Chirwa T, Ramdin T, et al. Comparison of morbidity and mortality of very low birth weight infants in a Central Hospital in Johannesburg between 2006/2007 and 2013. BMC Pediatr 2015;15:20.

22. Slater A, Shann F, McEniery J., ANICS Study Group. The ANZPIC registry diagnostic codes: a system for coding reasons for admitting children to intensive care. Intensive Care Med 2003;29:271-7. 